\title{
THE ELASTOPLASTIC CALCULATION OF FRAMES USING THE DISPLACEMENT METHOD
}

\author{
Alexander N. Potapov \\ South Ural State University (national research university), Chelyabinsk, RUSSIA
}

\begin{abstract}
We proposed a method for calculating statical indeterminacy frames taking into account plastic deformations, which is based on the use of a schematized diagram of material with hardening. Two types of standard beams with supports are used during the implementation of the displacement method (DM) and the elastic solution of the problem: "fixed" - "pinned" and "fixed" - "fixed", but unlike the elastic solution, standard beams contain plastic zones (PZs). So as the stresses in these zones did not exceed the limit of yielding in the nonlinear frame calculation, we took measures to transform the PZs into equal strength plastic zones (ESPZ). The calculations were made for both types of beams for all single and load impacts. The frame calculation consists of two stages (elastic and plastic). At the elastic stage, we determine an elastic moment diagram and the corresponding load. For a practical use of the DM in a nonlinear frame calculation, we introduced a simplifying prerequisite supplementing the well-known hypotheses of the classical version of the method, and formulated a Statement of the limiting load. According to the Statement, each length of the PZ can correspond to the lower boundary of the limiting load. The plastic stage of the calculation is performed at a given length of the PZ using the method of sequential loadings. At each loading stage, incremental equations are written using the DM equations, which establish relations between incremental moments and the incremental load, that allows you to get the resulting moment diagram. This diagram represents a sum of the elastic diagram and the diagrams of incremental moments at all previous loading stages. According to the resulting diagram, we calculate the length of the PZ, together with the limiting load. The calculation is considered complete if the length of the PZ does not exceed the specified value within the margin of error.
\end{abstract}

Keywords: displacement method, limit of yielding, stress, plastic zone, bending moment, stiffness

\section{УПРУГОПЛАСТИЧЕСКИЙ РАСЧЕТ РАМ МЕТОДОМ ПЕРЕМЕЩЕНИЙ}

\author{
A.H. Потапов \\ Южно-Уральский государственный университет (национальный исследовательский университет), \\ г. Челябинск, РОССИЯ
}

\begin{abstract}
Аннотация: Предложен метод расчета статически неопределимых рам с учетом пластических деформаций, основанный на использовании схематизированной диаграммы материала с упрочнением. При реализации метода перемещений (МП), как и при упругом решении задачи, используются два типа стандартных балок с закреплениями: «заделка» - «шарнир» и «заделка» - «заделка», но в отличие от упругого решения стандартные балки содержат пластические зоны (ПЗ). Для того, чтобы в нелинейном расчете рамы напряжения в этих зонах не превышали предел текучести, проведены мероприятия по преобразованию ПЗ в пластические зоны равного сопротивления (ПЗРС). Для обоих типов балок выполнены расчеты на все единичные и грузовые воздействия. Расчет рамы состоит из двух этапов (упругого и пластического). На упругом этапе определяются предельно-упругая эпюра моментов и соответствующая ей нагрузка. Для практического использования МП в нелинейном расчете рамы введена упрощающая предпосылка, дополняющая известные гипотезы классического варианта метода, и сформулировано утверждение о предельной нагрузке. Согласно утверждению, каждой длине ПЗ можно поставить в соответствие нижнюю границу предельной нагрузки. Пластический этап расчета выполняется при заданной длине ПЗ по методу последовательных нагружений. На каждой ступени нагружения с помощью уравнений МП записываются инкрементальные уравнения, устанавливающие связи между приращением изгибающих моментов и приращением нагрузки, что позволяет построить результирующую эпюру моментов. Эта эпюра представляет собой сумму предельно упругой эпюры и эпюр приращений моментов на всех предыдущих ступенях нагружения. По результирующей эпюре вычисляется длина ПЗ и соответствующая ей предельная
\end{abstract}


The Elastoplastic Calculation of Frames Using the Displacement Method

нагрузка. Расчет считается законченным, если длина ПЗ не превышает заданную величину в пределах погрешности.

Ключевые слова: метод перемещений, предел текучести, напряжение, пластическая зона, изгибающий момент, жесткость

\section{INTRODUCTION}

Elastic-plastic deformations are generally accounted within the framework of the limiting equilibrium theory (LET), which is based on the representation of an ideal elastic-plastic behavior of the material described by Prandtl diagram. The theory was developed by Soviet scientist Gvozdev A.A., who in 1938 formulated three basic limiting equilibrium theorems (static, kinematic and duality theorems) [1]. The creation of this theory allowed to developed effective methods for calculating and designing many structures, especially reinforced concrete (RC) structures. The provisions of the LET are included in the main regulatory documents [2, 3 ] on the calculation and design of modern structures.

In scientific literature, the concept of PZs is used mainly in seismic construction. For the first time, this concept was introduced by Paulay T. and Bull I.N. [5] in the calculation of RC earthquake-resistant frames. Experts are long familiar with the fact that plastic deformations have the ability to absorb seismic energy, transforming it into thermal energy and then dissipating it into the environment. The ability of loaded structural elements to absorb and dissipate energy generally ensures a decrease in the seismic impact on the frame. Thus, the structure, apart from its main designation, also works as an energy absorber. However, the operation of the structure beyond the limit of elasticity often leads to material degradation and destruction in these zones [6].

These developments aroused considerable interest among experts; they were consolidated in regulatory documents (codes) of the United States and other countries [7-9]. Studies related to determining the length of the PZ, its location in the structure, the number of PZs, etc. In most cases, we are talking about the features of the design of the PZs in RC [10-14] and metal [1518] structures under cyclic loads associated with seismic action.

In [10], a numerical analysis of the behavior of plastic hinges using the DIANA computing software, a calibrated FEM model was studied. On the extent of the rebar yielding zone, concrete crush zone and the real plastic hinge length a series of studies was conducted.

In [11-15] discuss issues of studying the plastic hinge length of RC columns. Moreover, in [11] for 4- and 7-story flat RC frames, studies were carried out in the SAP2000 8 program with the default (based on ATC-40 document [7]) hinges properties at both ends of beams and columns. In [12], based on the use of 3D FEM, it was shown that the PZ length for cyclically loaded columns is longer than for monotonic loading. An empirical model of the equivalent PZ length is proposed, which takes into account the effect of changes in this length on changes in the number of load cycles. In [13], the same ideas were applied to a fiber reinforced polymer. In [14], under the cyclic action of lateral force, the problem of assigning the PZ length in a RC column was studied and the role of the main reinforcement during its deformation beyond the limit of yielding into the hardening range was noted.

The design features of PZs in metal structures were considered in $[15,16]$, where a two-node super-element was developed for taking into account plastic deformations in steel frame structures in the analysis of static, cyclic [15] and impact [16] loads. In this case, in the superelement uses a model with two generalized (concentrated) plastic hinges located at the ends of the elastic beam element. When analyzing steel frames fabricated according to the «strong columns - weak beams» design concept [17], the authors proposed a composite beam-tocolumn connection, including a friction damper. 
In [18], experimental and analytical studies of seismic characteristics of the device proposed in [17] were continued, where its resistance to damage was noted when the length of the PZ at the ends of the beam was $1 \mathrm{p}=12 \mathrm{~cm}$.

In Russia and in the post-Soviet space, this problem is also reflected in [19-21]. It should be noted that both abroad and in Russian practice, the concept of PZs is considered as an equal strength zone [20], since its based on LET. Therefore, the stresses inside these zones should not exceed the limit of yielding $\sigma_{y l}$.

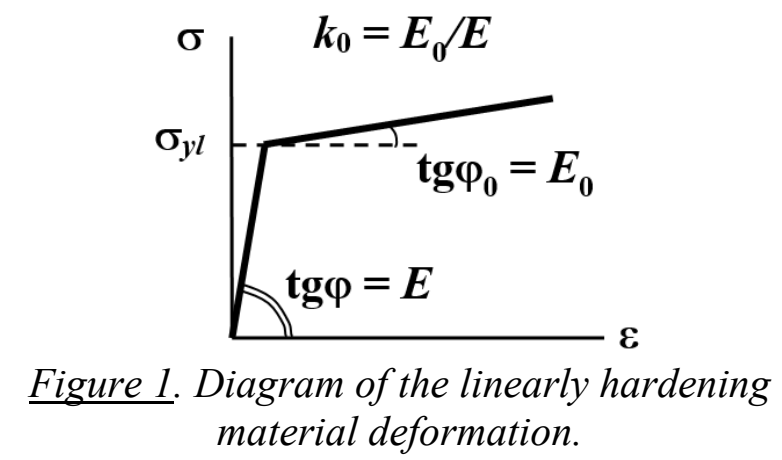

This article proposes a new approach to the calculation of statical indeterminacy frames using the DM, based on a physically nonlinear material deformation according to a hardening diagram (Figure 1). According to this diagram, when a limiting state appears in any section of the structure, a further load increase will lead to an increase in internal forces and stresses exceeding the limit yielding $\sigma_{y l}$ (Figure $2, a$ ). As a result, a PZ of some length $l_{p}$ will appear in the vicinity of the considered section, the stresses on the right boundary of which correspond to the limiting plastic stress (section 1, Figure 2, $b$ ). This boundary is determined by the level of the plastic moment $M_{0}=W_{0} \sigma_{y l}$, where $W_{0}$ is the plastic section modulus [4]. Normal stresses $\sigma_{\max }>\sigma_{y l}$ are inside this zone and in section 2 (Figure 2,c).

In order to ensure that the stresses in the PZ section do not exceed the yield strength and correspond to the plastic zone of equal strength (ESPZ), it is necessary to increase the stiffness of the element, requiring that the law of change in the stiffness of the element in this section be consistent with the law of change in bending moment.

\section{BASIC IDEA OF THE METHOD}

The solution of the problem of tranforming the area with nonlinear deformations into an equal strength plastic zone (ESPZ) should be integrated into the calculation algorithm of the method and performed in parallel with the nonlinear process of determining the limiting load for a given length of the PZ.
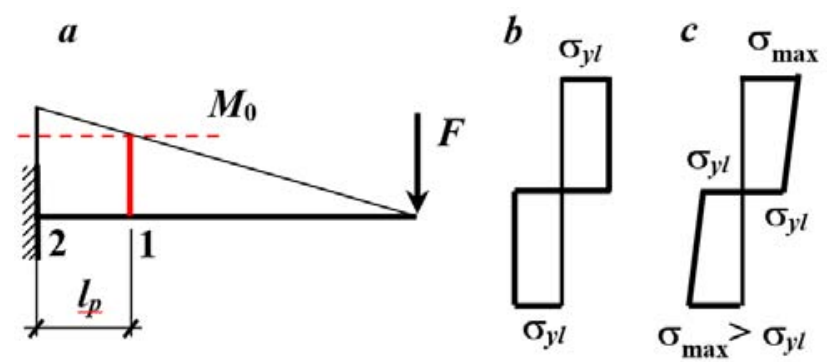

Figure 2. Yielding state in the beam:

$$
\begin{gathered}
a-P Z \text { with the length of } l_{p} \\
b-\text { stress in section } 1 ; \\
c-\text { stress in section } 2 .
\end{gathered}
$$

In case of a nonlinear calculation of statical indeterminacy frames by the DM, as well as in the classical version of this method, standard elements are used - beams with two types of supports: "fixed" - "pinned" and "fixed" "fixed", which should be designed for different types of unit and load impacts. However, in these calculations, a number of additional parameters should be taken into account related to the presence ESPZ. This is the relative length of the zone, its location in the span of the beam, the modulus of hardening of the material, the law of variation of the area moment of inertia within the length of the zone. Then, in addition to the known coefficients, the calculated characteristics will include additional dimensionless functions $f_{j}(\alpha)$,where $\alpha=l_{p} / l, l$ - beam length, characterizing the nonlinear operation of the standard element.

To simplify the nonlinear calculation, we introduce a new prerequisite for the modulus of elas- 
ticity of the elastoplastic section located between the elastic and plastic stress diagrams, hereinafter referred to as the intermediate section (IS). This prerequisite supplements the known hypotheses of the classical DM version, allowing us to control the deformed state of the frame model at the IS.

Prerequisite. For all the fibers of the intermediate section of the frame design model, the modulus of elasticity is assumed to be $k E$, where the coefficient $k$ is within $k \in\left[1, k_{0}\right]$.

Specifying the values of $k$ within $k \in\left[1, k_{0}\right]$, we can obtain estimates for various levels of the stress-strain state and limiting loads. At $k=1$, the IS is in a purely elastic state, which corresponds to the lower boundary of the limiting load. The deformed state at $\mathrm{k}<1$ can be considered as a consequence of an increase in the potential energy of the system spent on the development of plastic deformations in the IS and, as a result, leads to an increase in the ultimate load compared to its level in the elastic state of the IS.

Statement: For a given length of the PZ, the limiting load of the design model will be lower than the actual value of the limiting load, provided that the prerequisite condition is satisfied at $k$ $=1$.

Since at $k=1$ the stiffness of the rod in the IS is higher than the real stiffness of this section, the potential energy will be spent only on the creation of elastic deformations. They will be lower than the costs for the deformation of the elastoplastic section at $\mathrm{k}<1$. Therefore, these levels will determine the lower limits of ultimate loads.

The Statement is realized for the value of the plastic moment

$$
M_{0}=W_{0} \sigma_{y l}
$$

where $W_{0}$ is the plastic section modulus. The frame calculation consists of two independent stages (elastic and plastic). The elastic stage of the calculation includes determining of a bending moment diagram $M$ and finding of a critical section with the maximum moment $M_{\max }$ and the ratio

$$
m=M_{0} / M_{\max }
$$

By coefficient (1) is the ultimate elastic diagram of moments and ultimate load

$$
M_{e}=m M, F_{0}=m F
$$

It should be noted that the diagram $M_{e}$ is conditionally elastic, since, alongside with the elastic values of the moments, it contains the maximum moment equal to $M_{0}$.

The plastic stage of the calculation is performed at a given length $l_{p}$ using the method of sequential loadings. For each loading stage $d F_{0}$, we use incremental ratios connecting the diagrams of incremental moments and incremental loads. When determining the diagram of increments of moments, the basic system of the DM is used. For the first loading stage, the initial length $l_{p 1}$ can be taken based on the linear nature of the distribution of forces, for example, for the diagram $M_{e}$ multiplied by the coefficient

$$
n=1+d F_{0} / F_{0} .
$$

Based on the calculated correction (nonlinear) functions $f_{j}\left(\alpha_{1}\right)$ we form the coefficients (reactive forces) of the system of canonical equations and the right sides of the equations from incremental loads $d F_{0}$. After solving the system and obtaining the diagram of increments of moments $\mathrm{dMp} 1$, the resulting diagram is determined:

$$
M_{p 1}=M_{e}+d M_{p 1}
$$

from which we calculate the length $l_{p 2}$ for the next iteration step by the maximum value of the moment $\left(>M_{0}\right)$. We simultaneously determine the current limiting load:

$$
F_{p 1}=F_{0}+d F_{0}
$$

The obtained length is used to determine nonlinear functions $f_{j}\left(\alpha_{2}\right)$ for the second loading stage. In each $i$-th iteration, the following are calculated: the incremental moment diagram $d M_{p i}$, the resulting diagram $M_{p i}$, the limiting load: 


$$
M_{p i}=M_{p, i-1}+d M_{p i}, F_{p i}=F_{p, i-1}+d F_{0}
$$

and the PZ length $l_{p, i}$. The loading process continues until the obtained value does not reach the specified length $l_{p}$ according to the inequality:

$$
\left(l_{p}-l_{p, i+1}\right) \leq \text { eps. }
$$

\section{EQUAL STRENGTH PLASTIC ZONES}

As it follows from the review, during frame deformations caused by the seismic action, PZs can occur in the end parts of both horizontal (beams) or vertical (columns) frame elements. The procedure of design an ESPZ for horizontal frame elements is shown below (Figure 3).

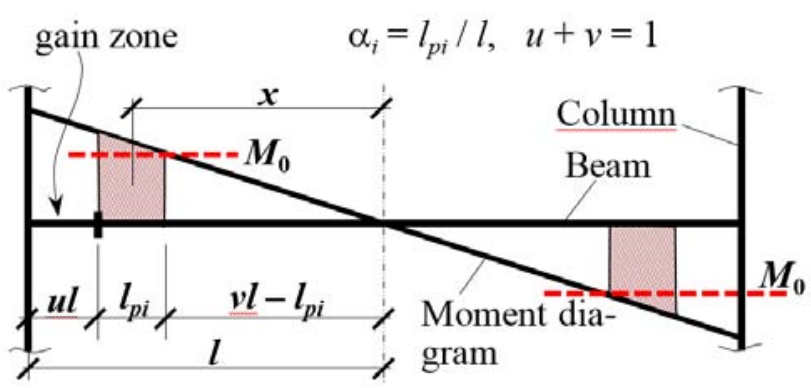

Figure 3. PZ in a beam of a seismic-resistant frame.

So that plastic deformations do not penetrate into the nodes of structural elements, according to the regulatory documents, the PZs are designed at a certain distance from the column. In this area (gain zone), the load-bearing capacity of the beam is ensured by increased rigidity. This is a mandatory requirement for both steel and RC structures [20,21].

Taking into account the shape of the moment diagram (Figure 3), we accept the linear law of variation of the area moment of inertia

$$
I_{x}=I \frac{x}{l\left(v-\alpha_{i}\right)},
$$

which ensures, within the limits of length $l_{p}$, an equal carrying capacity with stresses $\sigma_{y l}$.
For a standard beam supported according to the "fixed - pinned" scheme, shows all power characteristics from unit angle of rotation $\varphi=1$ are given (Figure 4). The correction nonlinear function $f_{1}$ has the form:

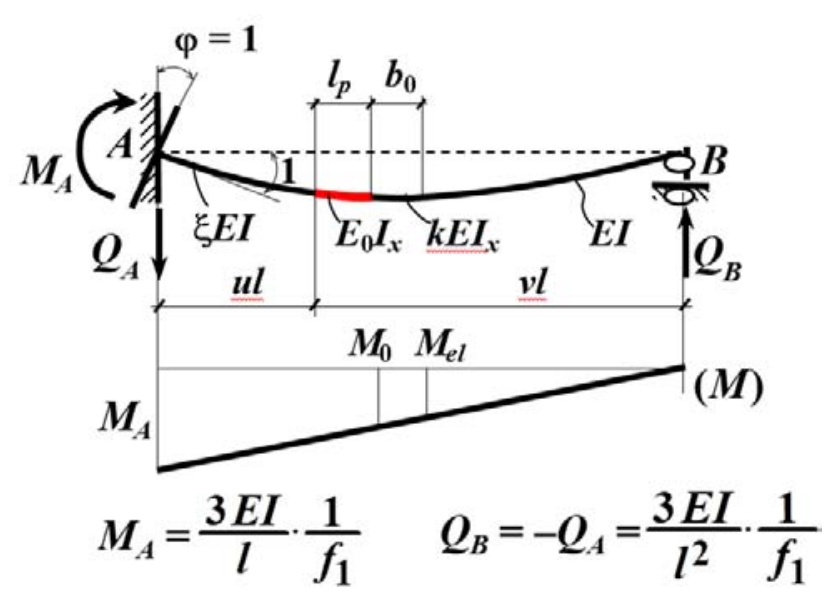

Figure 4. Beam with ESPZ ("fixed""pinned") at a unit angle of rotation.

$$
\begin{gathered}
f_{1}=\left(1-v^{3}\right) / \xi+3 \alpha_{i} b_{i}\left(v-\alpha_{i} / 2\right) / k_{0},+ \\
+\left[b_{i}{ }^{3}-\left(b_{i}-b_{0}\right)^{3} / k\right]+\left(b_{i}-b_{0}\right)^{3},
\end{gathered}
$$

where

$$
\begin{gathered}
b_{i}=\left(v-\alpha_{i}\right), \quad b_{0}=v\left(1-M_{e l} / M_{0}\right), \\
\alpha_{i}=l_{p i} / l, k_{0}=E_{0} / E,
\end{gathered}
$$

$\xi$ is the stiffness coefficient of the support (gain) zone; $b_{0}$ is the IS length.

The dimensionless function (6) contains four terms, each of which takes into account the contribution made to the overall ductility by the corresponding bar section, including the gain zone (1st term), the PZ (2nd term), and the IS (3 term). In the IS length formula (7), the elastic moment $M_{e l}$ is determined on the right IS boundary.

The second term in (6) was obtained for a section of the length $l_{p i}$ taking into account the variable stiffness (5):

$$
\begin{aligned}
& \delta_{p i}=\int_{v l-l_{p i}}^{v l} \frac{x^{2} d x}{E_{0} I_{x}}=\int_{v l-l_{p i}}^{v l} \frac{x l\left(v-\alpha_{i}\right) d x}{E_{0} I}= \\
& =\frac{l^{3}}{3 E I} 3 \alpha_{i}\left(v-\alpha_{i}\right)\left(v-\alpha_{I} / 2\right) / k_{0} .
\end{aligned}
$$


The proposed approach is illustrated by an example of a static calculation of a two-story frame on the action of horizontal forces simulating the seismic impact.

\section{EXAMPLE}

The design scheme of a two-story steel frame is shown in Figure 5, $a\left(F=40 \mathrm{kN}, F_{1}=-0,3 F, F_{2}\right.$ $\left.=F, l=300 \mathrm{~cm}, h_{1}=1,9 l, h_{2}=1.6 l\right)$. The frame material is C345 steel. The crossbar of the lower story is made of a wended I-beam № 27 (shelf sheet $0,65 \times 7,0 \mathrm{~cm}$; wall - sheet $0,5 \times 25,7 \mathrm{~cm}: I_{x}$ $\left.=2287,2 \mathrm{~cm}^{4} ; W_{x}=169,4 \mathrm{~cm}^{3}\right)$; the crossbar of the top floor and the vertical elements are made of twin channels № 20 (GOST 8240-72).

The strength characteristics are limits of yielding and strength, respectively: $\sigma_{e l}=345 \mathrm{MPa}$, $\sigma_{\mathrm{B}}=490 \mathrm{MPa}$. The modulus of elasticity is $E=$ $2,1 \cdot 10^{5} \mathrm{MPa}$, the modulus of hardening is $E_{0}=$ 647,33 MPa. The elastic moment and the plastic moment are, respectively: $M_{e l}=W_{x} \sigma_{y l}=58,45$ $\mathrm{kN} \cdot \mathrm{m}, M_{0}=W_{0} \sigma_{y l}=70,14 \mathrm{kN} \cdot \mathrm{m}$, where $W_{0}=$ $1,2 W_{x}$; flexural stiffnesses of the bars $-E I=$ $4803,08 \mathrm{kN} \cdot \mathrm{m}^{2}, E_{0} I=15,92 \mathrm{kN} \cdot \mathrm{m}^{2}$; the coefficient $k_{0}=0,0033$.

The preliminary calculation shows that the maximum bending moments occur in the end parts of the crossbar of the 1st floor. The PZ is designed at $u=0,05$ and $\xi=1,5$ (Figure 5,a).

The purpose of the example is to show how the lower (at $k=1$ ) boundaries of the limiting loads $F_{p}$ are determined for the given ESPZ lengths $l_{p}$ using the DM. We consider the PZ lengths from $2 \mathrm{~cm}$ to $14 \mathrm{~cm}$, which are multiple to the pitch of $2 \mathrm{~cm}$.

Due to the frame symmetry, the main DM system has four unknowns $Z_{k}$ (Figure $5, b$ ). The numbering of additional bonds is shown by the numbers in small squares. The relative length $\alpha_{i}$ of the ESPZ is formed in a nonlinear process at each $i$-th loading stage.

The pattern of solving the problem according to Statement at $k=1$ is shown below. From the preliminary frame calculation (at $F=40 \mathrm{kN}$ ), we obtain the highest stresses in section 6 (Fig. $5 a$ ) with a bending moment $M_{6}=63,43 \mathrm{kN}$
According to the elastic calculation results (at (1) $m=1,106$ ), we will obtain a moment diagram (2) $M_{e}$ containing the moment $M_{0}$ in section 6 and the limiting load $F_{0}=44,229 \mathrm{kN}$ (at $l_{p}$ $=0$ ). The diagram $M_{e}$ is shown on the right half of the frame (Fig. 6, blue, the values are given in brackets).
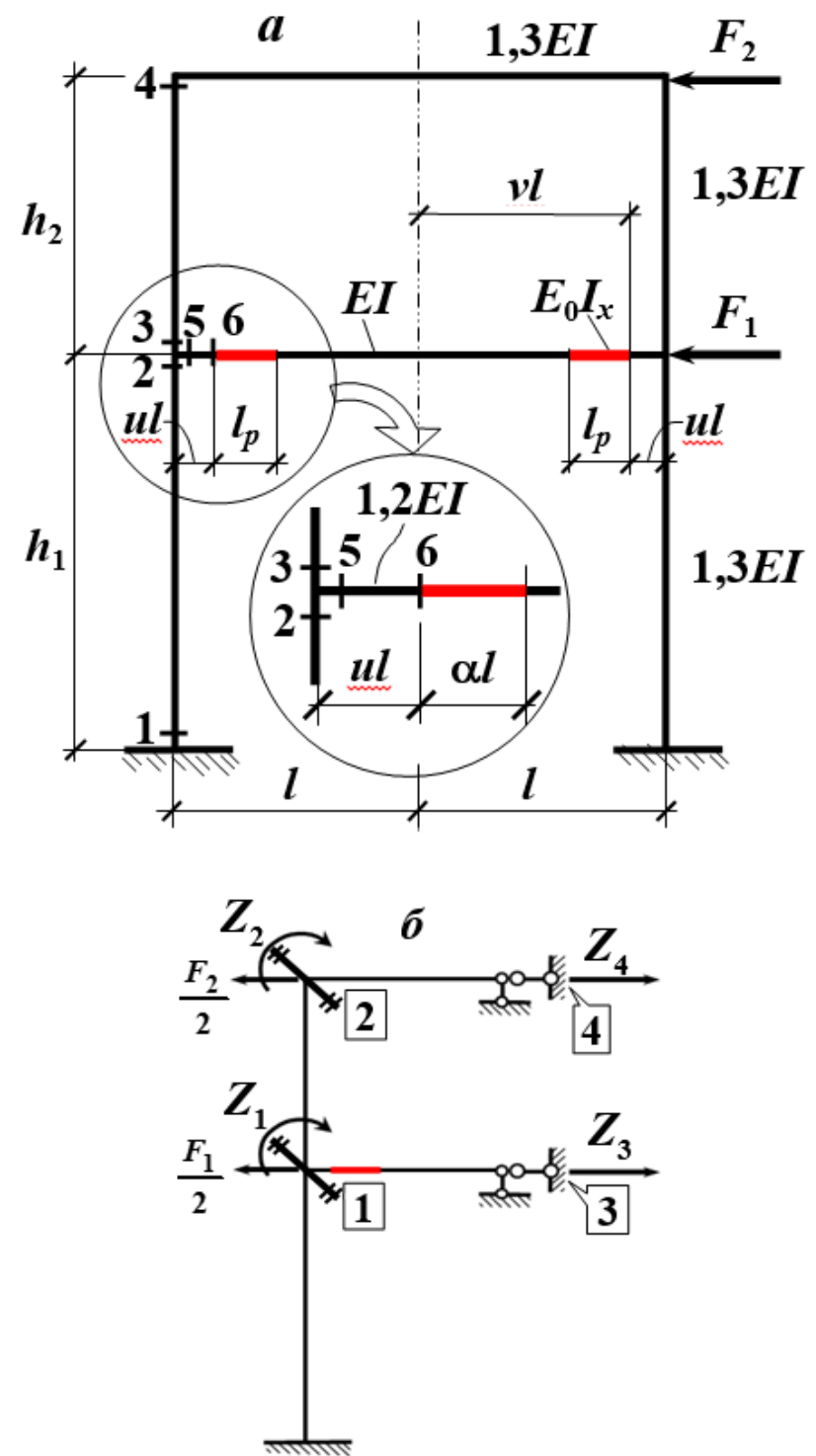

Figure 5. Design scheme of a two-story frame with PZs in the first-story crossbar (a); $b$ - main system of the DM.

In the nonlinear calculation, the system of incremental canonical equations at the $i$-th loading stage has the form: 
$K d Z+R_{d F}=0 \Leftrightarrow$

$\left[\begin{array}{llll}r_{11} & r_{12} & r_{13} & r_{14} \\ r_{21} & r_{22} & r_{23} & r_{24} \\ r_{31} & r_{32} & r_{33} & r_{34} \\ r_{41} & r_{42} & r_{43} & r_{44}\end{array}\right] \cdot\left[\begin{array}{l}d Z_{1} \\ d Z_{2} \\ d Z_{3} \\ d Z_{4}\end{array}\right]+\left[\begin{array}{l}R_{1 d F} \\ R_{2 d F} \\ R_{3 d F} \\ R_{4 d F}\end{array}\right]=0$,

where: $r_{11}=\left(6,121+3 \frac{1}{f_{1}}\right) \frac{E I}{l}, r_{12}=1,661 \frac{E I}{l}$,

$r_{13}=0,906 \frac{E I}{l^{2}}, r_{14}=-3,115 \frac{E I}{l^{2}}, r_{22}=7,31 \frac{E I}{l}$,

$r_{23}=-r_{14}, r_{24}=r_{14}, r_{33}=6,219 \frac{E I}{l^{2}}$,

$r_{34}=-3,894 \frac{E I}{l^{3}}, r_{44}=-r_{34}$;

$R_{1 d F}=R_{2 d F}=0, R_{3 d F}=-0,15 d F, R_{4 d F}=0,5 d F$.

A diagram of incremental bending moments for the 1st loading stage

$$
d F=0,0016 F_{0}=0,0708 \mathrm{kN}
$$

is shown on the left half of the frame (Figure 6).

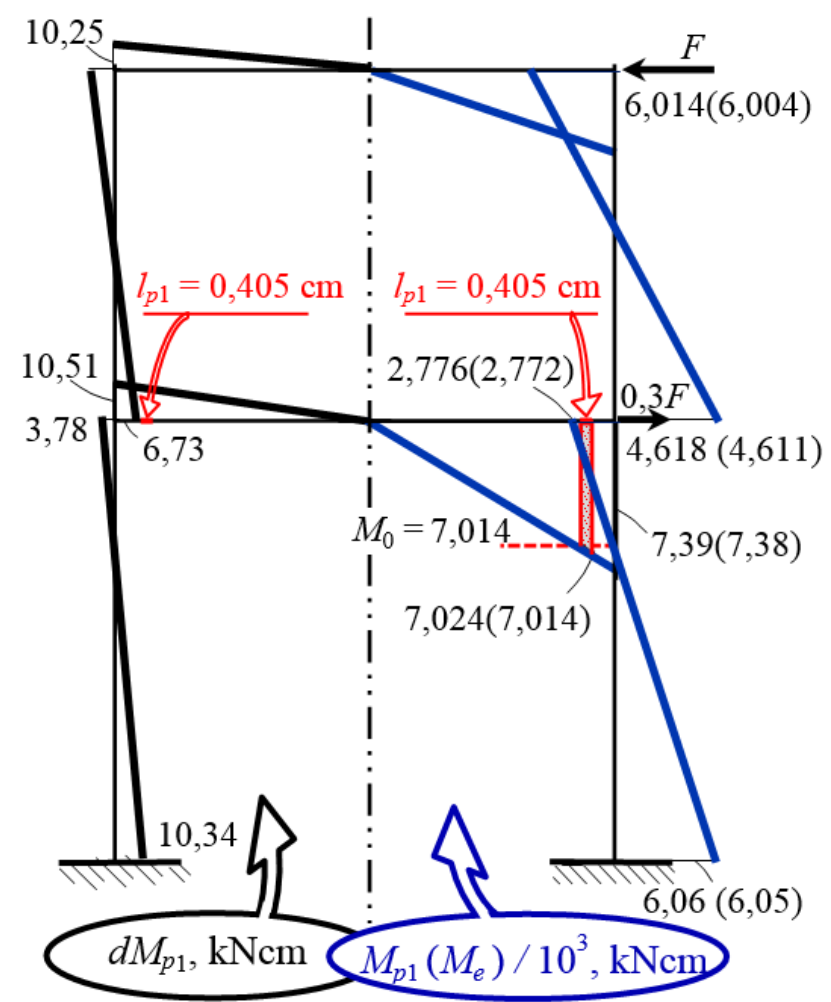

Figure 6. Bending moment diagrams

at the 1 st loading step at $l_{p 1}=0.405 \mathrm{~cm}$ :

to the left-incremental $d M_{p 1}$;

to the right-resulting $M_{p_{1}}\left(\right.$ elastic $\left.M_{e}\right)$.
At the initial stage:

$$
l_{p 1}=v l\left(1-M_{0} / M_{6}\right)=0,145 \mathrm{~cm}
$$

where

$$
M_{6}=1,0005 M_{0},
$$

we form the correction function (6) $f_{1}=1,399$. After solving the system of the canonical equations of the DM, we obtain the diagram of incremental moments $d M_{p 1}$ (shown on the left half of the frame, Figure 6) and the resulting diagram

$$
M_{p 1}=M_{e}+d M_{p_{1}}
$$

(shown on the right half of the frame, Figure 6). According to the results of the 1st iteration, the ESPZ length was $l_{p 2}=0,405 \mathrm{~cm}$, the load was

$$
F_{p 1}=F_{0}+d F=44,3 \mathrm{kN} \text {. }
$$

At the next loading steps for a given length $l_{p}=$ $2 \mathrm{~cm}$, the following results were obtained: $l_{p i}=$ $2,002 \mathrm{~cm}, F_{p i}=44,79 \mathrm{kN}$. The final nonlinear moment diagram $M_{p}$ is shown on the left half of the frame (Figure 7).

The bending moment at the left end of the ESPZ (section 6) was

$$
M_{6}=70,64 \mathrm{kNm}>M_{0}=70,14 \mathrm{kNm} .
$$

The stresses were:

$$
\begin{gathered}
\sigma_{1}=-202,3 \mathrm{MPa}, \sigma_{4}=200,6 \mathrm{MPa} ; \\
\sigma_{5}=243,8 \mathrm{MPa}<\sigma_{y l}=345 \mathrm{MPa} .
\end{gathered}
$$

The moment diagram $M_{p}$ for the length $l_{p}=14$ $\mathrm{cm}$ obtained at the limiting load $F_{p}=59,8$ $(65,18) \mathrm{kN}$ is shown on the right half of the frame (Figure 7). The results in brackets were obtained at the IS stiffness corresponding to the coefficient $k=0,5$. The stresses were:

$$
\begin{aligned}
& \sigma_{1}=306,5(344,7) \mathrm{MPa}, \\
& \sigma_{4}=303,7(342,4) \mathrm{MPa}, \\
& \sigma_{5}=305,5(305,5) \mathrm{MPa} .
\end{aligned}
$$




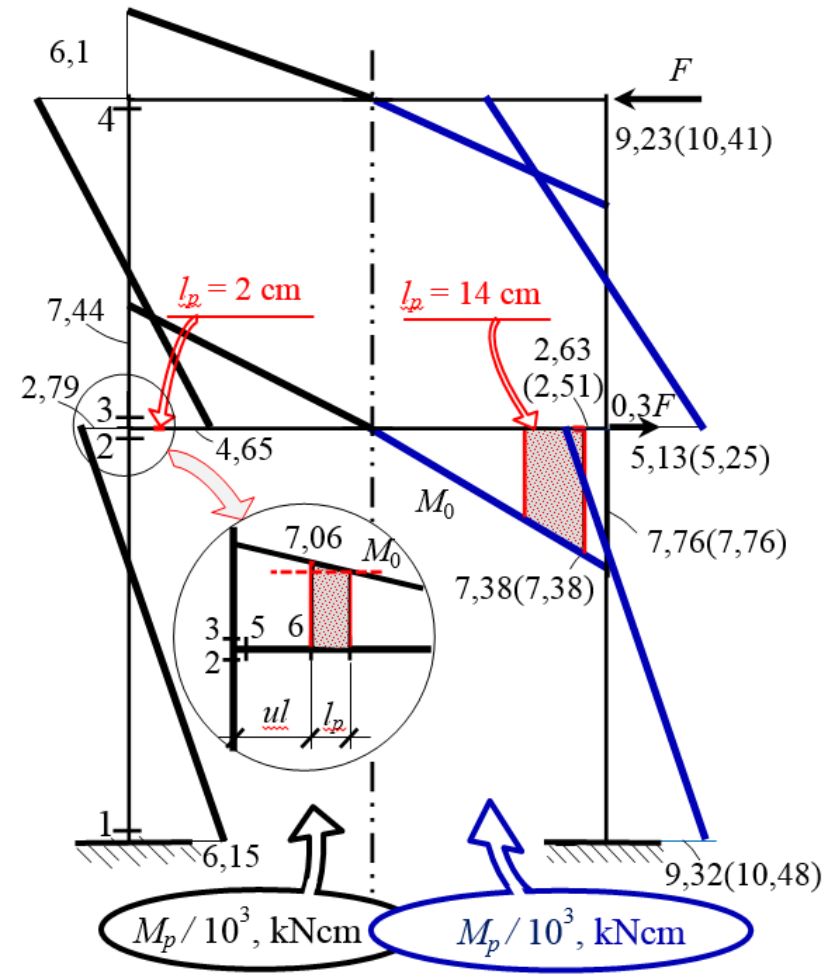

Figure 7. Bending moment diagrams $M_{p}$ at the ESPZ length: $l_{p}=2 \mathrm{~cm}$ (to the left); $l_{p}=14 \mathrm{~cm}$ (to the right; in brackets the results are at $k=0,5)$.

Figure 8 gives a general picture of the change in the lower boundary of the limiting loads depending on the ESPZ lengths obtained for the perfect elastic state of the IS (at $k=1$ ).

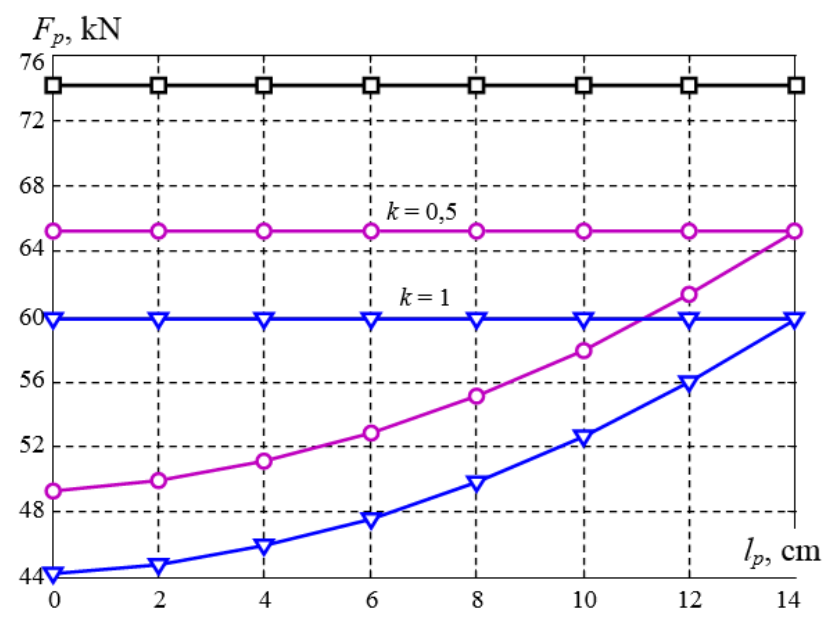

Figure 8. Limiting loads for the corresponding ESPZ: lower boundary $(k=1)$;

limiting load boundary at the intermediate section stiffness coefficient $k=0,5$.
When the IS stiffness decreases (at $k=0,5$ ), the boundary of the limiting loads increases. The failure load $P_{0}=74,07 \mathrm{kN}$ calculated by the limiting equilibrium method is presented as a black horizontal straight line.

Thus, when designing an ESPZ of a given length, we proposed an approach to the nonlinear calculation of statical indeterminacy frames based on the DM, using a one-sided assessment in the analysis of the stress-strain state of the design models. In addition to the limiting equilibrium method, this approach can be used in the design of structural systems in regions of an increased seismic activity.

\section{CONCLUSIONS}

1. An algorithm is proposed for the elastoplastic calculation of statical indeterminacy frames using the DM based on Statement 1, which allows us to determine the lower boundary of the limiting load for a given ESPZ length;

2. The calculations according to the proposed methodology allow us to estimate more effectively the limiting loads for the specified zones of yielding and, thereby, to create more cost-effective and reliable structures;

3. The calculation method when creating a PZ of equal resistance can be recommended when designing earthquake-resistant frames;

4. The proposed methodology can be used in the educational process when studying the discipline "Nonlinear Problems of Structural Mechanics".

\section{REFERENCES}

1. Gvozdev A.A. Raschet nesushhej sposobnosti konstrukcij po metodu predel'nogo ravnovesija [The Calculation of the LoadBearing Capacity of Structures by the Limiting Equilibrium Method]. Moscow, Stroyizdat, 1949, 280 pages (in Russian).

2. SP 63.13330.2012 (SNiP 52-01-2003) Betonnye i zhelezobetonnye konstrukcii. Osnov- 
nye polozhenija. Aktualizirovannaja redakcija SNiP 52-01-2003 [Concrete and Reinforced Concrete Structures. The Main Provisions (Updated version of SNiP 52-01-2003)]. Moscow, SUE Center for Design Products in Construction, 2012, 128 pages (in Russian).

3. SP 16.13330.2017 Stal'nye konstrukcii. Aktualizirovannaja redakcija SNiP II-23-81* [Steel Structures. Updated edition of SNiP II23-81*]. Moscow, Ministry of Construction of Russia, 2017, 148 pages (in Russian).

4. Birger I.A., Shorr B.F., Iosilevich G.B. Raschet na prochnost' detalej mashin [Strength Analysis of Machine Parts]. Moscow, Mashinostroyenie (Mechanical Engineering), 1993, 640 pages (in Russian).

5. Paulay T., Bull I.N. Shear Effect on Plastic Hinges of Earthquake Resisting Reinforced Concrete Frames, Structural Concrete under Seismic Actions. // Bulletin D. Information. Comite Euro-International du Beton. Paris, 1979, No. 132, pp. 165-172.

6. Travush V.I., Krylov S.B., Konin D.V., Krylov A.S. Ultimate state of the support zone of reinforced concrete beams. // Magazine of Civil Engineering, 2018, No. 7, pp. 165-174.

7. ATC-40 Seismic Evaluation and Retrofit of Concrete Buildings, California, USA, 1996. 334 pages.

8. NZS 3101. Part 2. 2. 2006 Code of Design Practice for the Design of Concrete Structures, New Zealand Standards Association, Wellington, 17 pages.

9. Eurocode 8 (EUR 25204 EN - 2012): Seismic Design of Buildings. Worked examples, 522 pages.

10. Zhao X., Wu Y.-F., Leung A.Yt., Lam H.F. Plastic Length in Reinforced Concrete Flexural Members. // Procedia Engineering, 2011, Volume 14, pp. 1266-1274.

11. Inel M., Ozmen H.B. Effects of Plastic Hinge Properties in Nonlinear Analysis Reinforced Concrete Buildings. // Journal of Engineering Structures, 2006, Vol. 28, pp. 1494-1502.

12. Yuan F., Wu Y.-F. Effect of load cycling on plastic hinge length in RC columns. // Journal of Engineering Structures, 2017, Vol. 147, pp. 90-102.

13. Yuan F., Wu Y.-F., Li C.-Q. Modelling plastic hinge of FRP-confined RC columns. // Journal of Engineering Structures, 2017, Vol. 131, pp. 651-668.

14. Megalooikonomou K.G., Tastani S.P., Pantazopoulou S.J. Effect of yield penetration on column plastic hinge length. // Journal of Engineering Structures, 2018, Vol. 156, pp. 161-174.

15. Alhasawi A., Heng P., Hjiaj M., Guezouli S., Battini J.-M. Co-rotational planar beam element with generalized elasto-plastic hinges. // Journal of Engineering Structures, 2017, Vol. 151, pp. 188-205.

16. Heng P., Alhasawi A., Battini J.-M., Hjiaj M. Co-rotating rigid beam with generalized plastic hinges for the nonlinear dynamic analysis of planar framed structures subjected to impact loading. // Finite Elements in Analysis and Design, 2019, Vol. 157, pp. 38-49.

17. Deng K., Wang T., Kurata M., Zhao C., Wang K. Numerical study on a fullyprefabricated damage-tolerant beam to column connection for an earthquake-resilient frame. // Journal of Engineering Structures, 2018, Vol. 159, pp. 320-331.

18. Deng K., Zheng D., Yang C., Xu T. Experimental and Analytical Study of Fully Prefabricated Damage-Tolerant Beam to Column Connection for EarthquakeResilient Frame. // ASCE Journal of Structural Engineering, 2019, Vol. 145, No. 3.

19. SNiP II-7-81*. Stroitel'stvo v sejsmicheskih rajonah [SNiP II-7-81*. Construction in Seismic Regions]. Gosstroy of Russia. Moscow: SUE Center for Design Products in Construction, 2002, 44 pages (in Russian).

20. Manual for the calculation and design of steel earthquake-resistant frames of multistory buildings (in the development of SNiP RK 2.03-04-2001). Part I., Ministry of Industry and Trade of the Republic of Kazakhstan (MIT of the RK). 2003, 52 pages 
(in Russian).

21. Sosnin A.V. Metodika dvuhstadijnogo rascheta armirovanija jelementov zhelezobetonnyh karkasnyh zdanij i sooruzhenij na dejstvie sejsmicheskih sil s primeneniem koncepcii nelinejnogo staticheskogo analiza. Chast' 1: Postanovka zadachi, struktura metodiki, informacionnaja baza issledovanija i strategija opredelenija parametrov zon plastichnosti [The Methodology of a TwoStage Calculation of Reinforcing Elements of Reinforced Concrete Frame Buildings and Structures on the Action of Seismic Forces Using the Concept of a Nonlinear Static Analysis. Part 1: Problem Statement, Methodology Structure, Research Information Base and Strategy for Determining the Parameters of Plasticity Zones]. // Bulletin of SUSU. Series "Construction and Architecture”, 2018, Vol. 18, No. 1, pp. 531 (in Russian).

\section{СПИСОК ЛИТЕРАТУРЫ}

1. Гвоздев А.А. Расчет несущей способности конструкций по методу предельного равновесия. - М.: Стройиздат, 1949. - 280 с.

2. СП 63.13330.2012 Бетонные и железобетонные конструкции. Основные положения. Актуализированная редакция СНиП 52-01-2003 (с Изменениями №1, 2, 3). М.: АО «Кодекс», 2012. - 128 c.

3. СП 16.13330.2017 Стальные конструкции. Актуализированная редакция СНиП II-23-81* (с Поправкой, с Изменением №1). - М.: АО «Кодекс», 2017. - 148 с.

4. Биргер И.А., Шорр Б.Ф., Иосилевич Г.Б. Расчет на прочность деталей машин. - М.: Машиностроение, 1993. - 640 с.

5. Paulay T., Bull I.N. Shear Effect on Plastic Hinges of Earthquake Resisting Reinforced Concrete Frames, Structural Concrete under Seismic Actions. // Bulletin D. Information. Comite Euro-International du Beton. Paris, 1979, No. 132, pp. 165-172.

6. Travush V.I., Krylov S.B., Konin D.V.,
Krylov A.S. Ultimate state of the support zone of reinforced concrete beams. // Magazine of Civil Engineering, 2018, No. 7, pp. 165-174.

7. ATC-40 Seismic Evaluation and Retrofit of Concrete Buildings, California, USA, 1996. 334 pages.

8. NZS 3101. Part 2. 2. 2006 Code of Design Practice for the Design of Concrete Structures, New Zealand Standards Association, Wellington, 17 pages.

9. Eurocode 8 (EUR 25204 EN - 2012): Seismic Design of Buildings. Worked examples, 522 pages.

10. Zhao X., Wu Y.-F., Leung A.Yt., Lam H.F. Plastic Length in Reinforced Concrete Flexural Members. // Procedia Engineering, 2011, Volume 14, pp. 1266-1274.

11. Inel M., Ozmen H.B. Effects of Plastic Hinge Properties in Nonlinear Analysis Reinforced Concrete Buildings. // Journal of Engineering Structures, 2006, Vol. 28, pp. 1494-1502.

12. Yuan F., Wu Y.-F. Effect of load cycling on plastic hinge length in RC columns. // Journal of Engineering Structures, 2017, Vol. 147, pp. 90-102.

13. Yuan F., Wu Y.-F., Li C.-Q. Modelling plastic hinge of FRP-confined RC columns. // Journal of Engineering Structures, 2017, Vol. 131, pp. 651-668.

14. Megalooikonomou K.G., Tastani S.P., Pantazopoulou S.J. Effect of yield penetration on column plastic hinge length. // Journal of Engineering Structures, 2018, Vol. 156, pp. 161-174.

15. Alhasawi A., Heng P., Hjiaj M., Guezouli S., Battini J.-M. Co-rotational planar beam element with generalized elasto-plastic hinges. // Journal of Engineering Structures, 2017, Vol. 151, pp. 188-205.

16. Heng P., Alhasawi A., Battini J.-M., Hjiaj M. Co-rotating rigid beam with generalized plastic hinges for the nonlinear dynamic analysis of planar framed structures subjected to impact loading. // Finite Elements in Analysis and Design, 2019, Vol. 157, pp. 38-49. 
17. Deng K., Wang T., Kurata M., Zhao C., Wang K. Numerical study on a fullyprefabricated damage-tolerant beam to column connection for an earthquake-resilient frame. // Journal of Engineering Structures, 2018, Vol. 159, pp. 320-331.

18. Deng K., Zheng D., Yang C., Xu T. Experimental and Analytical Study of Fully Prefabricated Damage-Tolerant Beam to Column Connection for EarthquakeResilient Frame. // ASCE Journal of Structural Engineering, 2019, Vol. 145, No. 3.

19. СНиП II-7-81*. Строительство в сейсмических районах (с Изменениями и дополнениями). - М.: ГУП ЦПП, 2002. - 44 с.

20. Manual for the calculation and design of steel earthquake-resistant frames of multistory buildings (in the development of SNiP RK 2.03-04-2001). Part I., Ministry of Industry and Trade of the Republic of Kazakhstan (MIT of the RK). 2003, 52 pages.

21. Соснин А.В. Методика двухстадийного расчета армирования элементов железобетонных каркасных зданий и сооружений на действие сейсмических сил с применением концепции нелинейного статического анализа. Часть 1: Постановка задачи, структура методики, информационная база исследования и стратегия определения параметров зон пластичности. // Вестник ЮжноУральского государственного университета. Серия: «Строительство и архитектура», 2018, том 18, №1, с. 5-31.
E-mail: potapov.alni@gmail.com.

Потапов Александр Николаевич, профессор, доктор технических наук; профессор кафедры «Строительное производство и теория сооружений», ЮжноУральский государственный университет (национальный исследовательский университет); 454080, Россия, г. Челябинск, пр. Ленина, дом 76;

тел.: +7(351) 267-91-83, +7(919) 343-71-29;

E-mail: potapov.alni@gmail.com.

Alexander N. Potapov, Dr.Sc., Professor; Professor of Department "Construction production and theory of structures", South-Ural State University (national research university); 76, Lenin Prospect, Chelyabinsk, 454080, Russia; phone: +7(351) 267-91-83, +7(919) 343-71-29; 